Edited by Jody H. Heiken, INC Division

Prepared by Elaine Roybal, INC-7

An Affirmative Action/Equal Opportunity Employer

This report was prepared as an account of work sponsored by an agency of the United States Government. Neither the United States Government nor any agency thereof, nor any of their employees, makes any uarranty, express or implied, or assumes any legal liability or responsibility for the accuracy, completeness, or usefulness of any information, apparalus, product, or process disclosen, or represents that its use would not infringe privately owned rights. Reference herein to any specific commercial product, process, or service by trade zame, trademark, manufacturer, or otherwise, dors not necessarily constitute or imply its endorsement, recommendation, or favoring by the United States Government or any agency thereof. The views and opinions of authors expressed herein do not necessarily state or reflect those of the United States Government or any agency thereof. 
$L A--12014-M S$

DE91 007314

Survey of Hazardous Materials

Used in Nuclear Testing

Ernest A. Bryant

June Fabryka-Martin

\section{MASTER}

DISTFIBUTION OF THIS DOCUMENT IS UNLIMITED

$p^{2}$

[_(0)S A 


\title{
SURVEY OF HAZARDOUS MATERIALS USED IN NUCLEAR TESTING
}

\author{
by \\ Ernest A. Bryant \\ and \\ June Fabryka-Martin
}

\begin{abstract}
The use of "hazardous" materials in routine underground nuclear tests at the Nevada Test Site has been reviewed. In addition the inventory of test yields, originally reported in 1976 has been updated. A trial "down-hole inventory" has been conducted for a selected test. The inorganic hazardous inaterials introduced during testing (with the exception of lead and the fissionable materials) produce an incremental change in the quantity of such materials already present in the geolngic media surrounding the test points.
\end{abstract}

\section{INTRODUCTION}

Because of current concerns about the potential environmental impact of "weapons complex" activities, underground testing practices at the Nevada Test Site (N'TS) have been reviewed to obtain a general understanding of the nature and quantity of "hazardous" materials used in the underground test environment. This information can serve as the basis for an evaluation of potential environmental impacts resulting from migration of hazardous waste material away from the sites of the nuclear explosions.

This report summarizes the results of such a review in four sections: (1) a summary of the history of underground nuclear testing, (2) a description of current test practices, (3) a summary of sources for test material information, and (4) the results from a trial inventory for a specific test. The first section covers testing, by both Los Alamos National Laboratory (LANL) and Lawrence Livermore National Laboratory (LLNL), but the other sections relate only to LANL testing. A very brief introduction to relevant hazardous material definitions appears in the Appendix. 


\section{BRIEF SUMMARY OF UNDERGROUND TESTING AT THE NEVADA TEST SITE}

To gain a perspective on the nature and quantity of hazardous materials used at the Nevada Test Site (NTS), it is useful to briefly summarize relevant information about the underground testing that has taken place there. Many of the same materials are used for each nuclear test, so it is useful to know how many tests have taken place. To the extent that larger quantities of materials are needed for larger explosions, the inventory of hazardous waste may be proportional to total test yield rather than to the number of tests. Also the degree of dilution of hazardous materials by mixing with melted and volatilized geologic materials depends on the energy released by the test. Thus it is of interest to document both the number and total yield of the nuclear tests.

Fi sm the beginning of underground testing of weapons at the Nevada Test Site in 957 through February 1990, a total of 616 publicly announced underground nuclear tests have occurred. (A1I subsequent references to tests in this document are 1 imited to publicly announced tests.)

The number of tests conducted near or below the water table is of particular interest relative to hazardous waste migration in ground water. There have been 172 tests for which the shot points or lower cavity edge lay below the standing water leve1 (SWL) (Table I). Of these tests, $52 \%$ have been in Yucca Flats and $39 \%$ in Pahute Mesa.

The total fission yield for NTS events conducted below the water table or with a cavity edge extending below the water table, as of February 1990, is about 28 megatons (Mt), which is a factor of 4 larger than the value estimated by Borg et al. (1976) for the period ending June 1975 (Table II). Expressed in terms of yield, $68 \%$ of the "ground-water - accessible" radionuclide inventory was deposited in Pahute Mesa.

TABLE 1. DISTRIBUTION OF ANNOUNCED UNDERGROUND TESTS AT THE NTS (1957-1990)

Shot Point Lower Cavity Lower Cavity Cavity Total Below SWL Below SWL $\leq 75 \mathrm{~m}$ Above
SWI. $\begin{gathered}>75 \mathrm{~m} \\ \text { Above SWL Events }\end{gathered}$

\begin{tabular}{|c|c|c|c|c|c|}
\hline Pahute Mesa & 33 & 33 & 6 & 5 & 77 \\
\hline South Yucca Flat & 10 & 4 & 23 & 140 & 177 \\
\hline North Yucca Flat & 67 & 23 & 32 & 189 & 311 \\
\hline Frenchman Flat & 1 & 1 & 2 & 0 & 4 \\
\hline Rainier Mesa & 0 & 0 & 0 & 47 & 47 \\
\hline TOTAL NUMBER & $\overline{111}$ & $\overline{61}$ & 63 & $\overline{381}$ & $\overline{616}$ \\
\hline
\end{tabular}

Definition of geographical units: Pahute Mesa - areas 18,19,20; South Yucca Flat = areas 1,3,6,11; North Yucca Flat a areas 2,4,7,8,9,10,15; Frenchman Flat = area 5; Rainier Mesa - area 12. 
TABLE 2. GEOGRAPHICAL DISTRIBUTION OF TEST YIELDS FOR CASES IN WHICH THE DEPTH OF BURIAL OR CAVITY EDGE EXTENDED BELOW THE WATER TABLE

\begin{tabular}{lcc} 
& $\begin{array}{c}\text { Borg Report } \\
\text { (as of 6/75) }\end{array}$ & $\begin{array}{c}\text { Updated Estimate } \\
\text { (as nf 2/90) }\end{array}$ \\
\cline { 2 - 3 } & $4 \mathrm{Mt}$ & $19 \mathrm{Mt}$ \\
Pahute Mesa & $3 \mathrm{Mt}$ & $9 \mathrm{Mt}$ \\
Yucca Flat & $<0.01 \mathrm{Mt}$ & $<0.01 \mathrm{Mt}$
\end{tabular}

SUBTOTAL

$7 \mathrm{Mt}$

$\overline{28 \mathrm{Mt}}$

\section{WEAPONS TEST PRACTICES}

The various steps involved in conducting a nuclear test are described in the following subsections. In each case there is special emphasis on the introduction and/or redistribution of materials in the vicinity of the test.

\section{A. Drilling and Hole Preparation}

Emplacement holes are presently $96 \mathrm{in.} \mathrm{in} \mathrm{diameter.} \mathrm{Emplacement} \mathrm{holes} \mathrm{are}$ drilled with polymer or detergent and water by a dual-string reverse circulation method, which in recent ears replaced the conventional circulation method that used bentonite or sepiolite mud.

Samples of drilling fluid are collected daily by Los Alamos Group HSE-1 to analyze for gross radioactivity; water samples are collected for ${ }^{3} \mathrm{H}$ assay.

A steel casing is always installed and extends down 30 to $100 \mathrm{ft}$ from the surface. If the test point is below the SWL, a liner is also installed in the bottom of the emplacement hole and the hole is blown dry. Otherwise, no liner is installed. Cement grout is placed around the casing and liner.

\section{B. Nuclear Device and Rack}

Each test involves a test rack, a steel structure that supports the nuclear device to be tested and various instruments to measure the results of the test. Racks are typically more than $100 \mathrm{ft}$ in height and include from 2 to as many as 20 line-of-sight pipes, each with a window of a composition compatible with the desired measurement (aluminum, beryllium, etc.). The rack sits on top of a steel canister that contains the device. The anister is often lined with a mixture of boron and polyethylene.

The racks are fabricated and assembled under the direction of the LANL Test Engineering Group, J-7. Detectors are designed by Groups P-14 (Fast Transient Plasma Measurements Group) and P-15 (Neutron Measurements Group) and fabricated by EG\&G; some specific parts may be provided by the experimenter. Occasionally, experiments or objects are included on the rack for other groups, such as Group J-8 (for timing and firing). Such items are generally coordinated with $\mathrm{J}$ Division and/or P Division. 
Large quantities of polyethylene are used on the racks. Other organic materials used include polyvinyl chloride (PVC), Teflon, polystyrene, phenolic, and neoprene. Possibly hazardous organic chemicals include complex fluorescing compounds (liquid scintillator), and laser dyes used as part of some detector packages.

Among the inorganic hazardous materials, lead is used extensively. Typically tens of tons are used for shielding in both the canister and rack.

Copper is also used: always for wiring but sometimes for other purposes such as shielding. Beryllium, nickel and zinc may be present in small quantities in detector packages ( $100 \mathrm{~g}$ ). Arsenic, chromium, cadmium, osmium and thallium have been used in rare instances. Other commonly used metals include tungsten, tantalum, stainless steel (iron, chromfum, and nickel), and aluminum.

Each test device contains nuclear materials such as uranium, plutonium, tritium, 1ithium and structural materials such as steel, aluminum, beryllium, gold, etc. Radiochemical detectors (for example, yttrium, zirconium, thulium, lutetium) and tracers (isotopes of uranium, plutonium, americium, or curium) are also used. The exact amount of each used in any given device cannot, of course, be reported in an unclassified document. Generally the detectors and tracers are used in less than $100-\mathrm{g}$ quantities.

\section{Back-F111}

Magnetite (major ingredient $\mathrm{Fe}_{3} \mathrm{O}_{4}$ ) powder is poured downhole to cover the sides and top of the rack. This naturally occurring material contains thorium and a variety of other impuxities such as heavy rare earths.

Stemming materials are used tc prevent the escape of radioactivity from the device upwards in the emplacement hole. The stemming consists of layers of pea gravel alternating with layers of "fines" (fine gravel), all of which is native material from the NTS shaker plant, and two or more special plugs placed well outside the melt zone. The plugs are made of either two-part epoxy (TPE) or coal-tar epoxy (CTE) and remain intact following the test.

\section{Detonation}

The explosion initially creates an approximately spherical cavity filled with gases that are formed by atomization and vaporization of materials from the explosive device and its immediate surroundings. The molten cavity walls subsequently flow down to form a puddle that later freezes to form glassy material. At some time, the rock above the cavity generally falls down to fill the cavity with rubble; this chimney-forming process may proceed upward all the way to the surface to form a crater, or it may stop at some intermediate point. Vaporized material is condensed and incorporated into molten rock or escapes into the chimney rubble where it may condense on solid rock. Volatile elements/materials tend to be enriched in the rubble zone, whereas refractory materials tend to remain in the puddle glass.

The melt zone created by the nuclear test incorporates a mass (expressed in tons) of the same order of magnitude as the device yield (expressed in tons); thus the 
zone would extend beyond the top of a $30-\mathrm{m}$ rack if the yield is about $100 \mathrm{kt}$ or more. In every test with a significant nuclear energy release, the entire device is atomized and mixed with a relatively large quantity of rock.

\section{E. Re-Entry}

Drill-back for diagnostic sample recovery involves drilling a hole, normally about 10-in. in diameter, at an angle that is directed to intercept the test debris puddle near its center. A profile of the radioactive material distribution along the hole is measured with a downhole Geiger counter, and then samples of the puddle glass are collected with a sidewall core sampler. The drilling procedure uses drilling mud with various additives. A significant fraction of the mud is generally lost downhole into the more-or-less open structure of the rubble created by the test. Whereas LLNL uses "air-foam" for the upper part of the drill-back hole, LANL almost always uses mud for the entire hole.

Drilling mud is prepared by pumping water from a water-supply well to a surface impoundment and then to the REECo Mud Plant. At this time, water for drilling in the flats is obtained from wells $C, C-1$, and $C-4$; wells $A$ and UE1r were used in the past but were shut down a few years ago. On Pahute Mesa, local water wells and a portable mud plant are used. An inventory of drilling-mud components stocked in the REECo Mud Plant was assembled by Barbara Hargis (formerly of Group HSE-8) for Dale Engstrom (Group J-6) in 1989 and appears in Table III.

Hazardous chemicals included in the table are chrome (in Raykrome 400), ethylenediamine (in Soda Ash), and paraformaldehyde (in Magcocide and My-Lo-Jel preservative). The unofficlal memo to Dale Engstrom notes that other chemicals have been used in formulating the drilling mud, but that they are ordered only when necessary and are not stocked.

Drilling fluids are sampled at irregular intervals by several groups.

D. Henderson of Group HSE-1 monitors drilling fluids for radioactivity during drilling of new emplacement holes. During 1989, Tony Grieggs of Group HSE- 8 sampled mud from three drill-backs (UE19ay, UE7bk, and U4s) to determine whether the mud should be classified as hazardous waste because of its heavy metal or organic contents. The mud samples were analyzed by Group HSE-9 for eight toxic metals as well as for semi- and volatile organics, using a variety of US Environmental Frotection Agency (EPA) approved procedures. None of the muds exceeded EPA toxicity limits; in fact, the levels were lower than the limits by more than an order of magnitude in every case. Relatively few organics were seen, and $T$. Grieggs suggests that those seen may be traceable ejther to contamination in the laboratory or to petroleum breakdown products. More sampling is tentatively planned for 1990 .

\section{RECORDS OF MATERIAL USED IN NUCLEAR TESTS}

Information concerning the nature and quantity of materials placed downhole during the process of conducting a nuclear test must be obtained from a number of sources for any given test. Generally records for a given operation are kept by only one organization. 


\section{A. Drilling Records (Field Engineering, Croup J-6, Dale Engstrom)}

Drilling is carried out by REECo under the direction of Group J-6; REECo writes a daily drilling report on each hole. Phyllis Rashki of REECo also maintains drilling records with respect to hazardous waste considerations. Fenix and Scisson, the engineering contractor for drilling, compiles the history and data for each hole, which is then sent to Group J-6, the Department of Energy at NTS, Jack House, Program Manager for Containment (EES-DO), and Group EES-3 (Containment). The Group J-6 records are sent to LANL Central Storage after about 1 year.

TABLE III. MATERIALS USED IN DRILLING AT NTS ${ }^{a}$

Trade Name

\section{INORGANIC MATERIALS}

Hydrogel, Big Horn, or Envirogel

Thermogel

Caustic soda

"Potash"

ORGANIC MATERIALS

Cypan

Thatcher Foamer TF

Magcono1

Cydril 4000 Flocculant

Soda Ash

Guar Gum

Rapid Mud

Raykrome 400

My-Lo-Jel

Polysal

Magcocide

My-Lo-Jel preservative

COMPOSITION UNKNOWN

Magco Foam Check

\section{Chemical Material}

Sodium montmorillonite, Western Bentonite

Sepiolite

$\mathrm{NaOH}$

$97 \% \mathrm{KCl}$

Sodium polyacrylate (polymer)

Surfactant TF foamer containing isopropanol

Alcohol

Anionic polyacrylamide

Contains theophylline, ethylenediamine, carbonic acid disodium salt

Galacto-mannans $\left(\mathrm{C}_{6} \mathrm{H}_{10} \mathrm{O}_{5}\right)_{n}$

Liquid anionic polyelectrolyte (organic)

Chrome lignosulfonate, contain: $4 \% \mathrm{Cr}$

Pre-gelatinized starch

Modified starch (drilling fluid compound to reduce fluid loss)

91\% paraformaldehyde (EPA hazardous chemical)

95\% paraformaldehyde (EPA hazardous chemical)

Proprietary mixture

aCompiled by B. Hargis (Group HSE-8) for D. Engstrom (Group J-6). 


\section{B. Rack and Canister Materlals}

There is not a data base that lists the materials contained in each rack; however, the Coordinator designated for each test can provide an overall picture of the various experiments on the rack. Information on rack contents can generally be obtained from four different sources:

(1) Rack drowings, maintained in the Group J-7 Office, Building SM-216. These drawings include details of the rack structure, shielding, and each experiment but generally not the detectors (measurement devices) within each experiment.

(2) Detector handbook, maintained by EG\&G. This handbook documents detectors and their components. Such information can alternatively be found in P-Division files. All detectors are built by EG\&G under an extensive QA plan.

(3) Group P-14 or Group P-15 Progress Reports or "shot reports" prepared by an experimenter for a particular experiment. These reports describe custom parts supplied by individual experimenters. Shit reports are distributed at the discretion of the experimenter but generally go to X Division office (X-DO), P-DO, J-DO, and Groups X$2, \mathrm{X}-4, \mathrm{P}-14$, and $\mathrm{P}-15$.

(4) Laboratory notebooks of individual experimenters. In some instances, the materials in a particular experiment may be known only to the experimenter and can be found only in his laboratory notebook. This practice was probably more common in the past.

\section{Device Materials}

It is well known that nuclear devices may contain or produce radioactive isotopes of the actinides (uranium, neptunium, plutonium, and americium in particular), tritium, and fission products. In addition, various metals may be incorporated as structural materials or as neutron flux monitors. The nature and quantity of ingoing materials is very well documented in Classified data bases. They will not be discussed further in this Unclassified report.

\section{Relevant Data Bases}

(1) The shot book maintained in INC-Division vault. This ... uple chronological listing of all US tests, starting with Trinity in 1945 and including those that occurred outside the NTS, contains shot number, name, laboratory, date and time, emplacement area and hole, and location (for example, underground depth and type of rock).

(2) Containment reports for individual tests. These reports are currently prepared by EES Division and are available for all LANL tests. Similar reports are available for a few LLNL tests. These reports include information on

- hole construction and drilling logs; $x$-ray analyses of drill cuttings; materials used for drilling and grouting;

- nearby holes; 
- diagnostic line-of-sight assemblies and plugs for each assembly (for example, plug compositions include aluminum, lead, copper, bromine, iron, tungsten, PVC, and polyethylene $\left.\left(\mathrm{CH}_{2}\right)\right)$;

- einplacement hole design plans for containment (back-fill material and plugs);

- site geology, nearby faults, stratigraphy, 1ithology, geologic cross-sections; and

- event yield, diagnostics system, working point parameters (such as porosity, geology, and depth to water table), containment design (for example, thickness and composition of layers and plugs).

(3) COEDS (COmmon Event Data System) (Nancy Marusek, Group EES-5 and Project Leader, Don Shirk, Group X-5). This data base includes data for both IANL and LLNL tests. Several divisions maintain tables within this system, including INC, $X, J, ' N X$, and EES. Types of data include depth of burial, water level, measured and estimated cavity radius, and test yield.

(4) GEODES (GEOlogic Data Evaluation System) (Nancy Marusek, Group EES -5). The GEODES data base contains downhole information on LANL tests, including lithologic logs, location, and SWL.

5. Pre-shot data base (Tim Benjamin, Group INC-7). This data base is maintained by Groups INC-7 and 11 (Scott Bowen and Zita Svitra) on the INC DP2 Classified VAX and contains SECRET RESTRICTED DATA. It includes most LANL tests but many LLNL tests are missing. The data base contains material summaries for the nuclear device. It includes all major elements, plus those trace elements that could conceivably be of significance for diagnostic interpretations. It also includes isotopics of fissile material and elemental compositions taken from design engineering drawings from WX Division. Analyses of isotopic signatures and assays of impurities are based on information from CLS or INC Divisions, Rocky Flats, or other sources.

6. Post-shot data base (TIm Benjamin, Group INC-7). This data base is maintained by Groups INC-7 and INC-11 on the INC DP2 Classified VAX. It contains concentration and isotopic data from analyses of drillcore samples for fission products, actinides and radiochemical detectors as measured by INC-Division staff.

\section{TRIAL INVENTORY FOR THE AMARILLO TEST}

The accessibility and quality of data available to estimate a complete downhole inventory was tested by compiling available information for Amarillo, which was fired June 27, 1989, in emplacement hole UE19ay. This test was selected because its yield was fairly typical; it was conducted below the water table; and it was one of the three tests sampled by Tony Grieggs of Group HSE-1 to evaluate drillback mud as a potential hazardous waste. 
The following sections discuss the data source and the nature and amounts of hazardous chemical wastes emplaced downhole.

\section{A. Emplacement Hole Drilling}

A copy of the Fenix \& Scisson, Inc., "Hole History Data" was provided by Group $\mathrm{J}-6$. This document summarizes the activities for each day of hole preparation and the amounts of Rapid Mud and cement used. No hazardous materials were identified.

B. Rack

A complete set of rack drawings was provided by Group J-7. These drawings identified materials but (except for lead) generally not the amounts used; these amounts could be deduced from volume and density. The following materials wure used at one ur more locations: lead, tungsten, PVC, steel, aluminum, brass, copper, polyethylene, boron, tantalum, shrink-tubing (teflon?), stainless steel, phenolic, neoprene, and styrofoam. Amounts of materials were listed in a "Rack Work Summary;" for example, total lead was about 126000 lbs (this also appears in the Group J-6 summary), and about 1000 lbs of tungsten was used. The rack structure itself weighed 68000 lbs when it was "made vertical" in preparation for installing experiments, shielding, etc. The final rack weight was $231000 \mathrm{lbs}$ and the harness plus cables weighed $215000 \mathrm{lbs}$. A total of 4250 1bs of Boron-Polyethylene mix was used.

\section{Dlagnostic Instruments}

Because there is no compilation of the materials used in the diagnostic instruments, the inventory for these materials was based on conversations with the Diagnostic Coordinator (Marion Stelts, Group P-15) and individual experimenters (Dale Glasgow - Nuex, THREX; John Stokes - HFK, Compton diodes; David Platts - micro-interferometry; and Michael Hynes - PINEX). M. Hynes was on sabbatical during the inventory, so contact was made with John Warren. $\mathrm{J}$. Ogle, of Group P-14, provided additional informatior concerning the amounts of fluorescing material used.

(1) Group P-14. The Compton diode and HFK detectors used for Amarillo contained $1.0 \mathrm{~kg}$ of $\mathrm{BC}-400$ (a polyvinyltoluene (PVT) based fluorescing material with a small quantity of possibly hazardous organic material).

(2) Group P-15 - NUEX, THREX. Although gallium arsenide and indium phosphide are sometimes used, they were not used on Amarillo. The instruments consisted of converters followed by Faraday cup or Si(Li) detectors. No hazardous materials could be identified as being associated with these detectors.

(3) Group P-15 - PINEX. The detector used here contained $1.7 \mathrm{~kg}$ of BC-422 (a PVT-based fluorescing material with a small quantity of possibly hazardous organic material). 


\section{Composition of Device (not including Special Nuclear Materials)}

This composition was based on preshot data base and drawings. A number of hazardous metals were identified in small quantities (less than $1 \mathrm{~kg}$ ) in the device materials. There were also a number of organic materials present in small quantities; except for the high explosive, none of these could be identified as hazardous. Note that all che organic materials in the device were completely destroyed during the explosion.

Detailed device composition is classified information and is not presented here.

E. Stemming.

Detailed records of stemming materials were provided by Group J-6. A "Stemming and Harness Diagram" shows the depths of the rack, magnetite, grout, the alternating coarse-fine layers of fill, and the series of three two-part-epoxy (TPE) plugs. A folder titled "Downhole stemming Notes" provided data on the volume of TPE and grout and the weight of the coarse and fine fill materials. A typical truckload of grout contained 5700 lbs of grout cement, 815 lbs of gel, $6740 \mathrm{lbs}$ of barite, and $65 \mathrm{lbs}$ of D-19 (de-watering agent); seven truckloads were used. The TPE plug No. 1 used six truckloads of mix, each containing 350 gal. of epoxy $\mathrm{mix}, 12675 \mathrm{lbs}$ of aggregate and $5075 \mathrm{lbs}$ of sand. The epoxy currently used in the TPE mix is reported to be non-hazardous by Group J-6.

\section{F. Dri11-back}

The Fenix \& Scisson Hole History indicates that the drill-back hole used 13585 bbl of bentonite and $7518 \mathrm{bbl}$ of sepiolite. The hole was plugged with $825 \mathrm{ft}^{3}$ of cement.

\section{G. Summary of Trial Inventory}

Data was available for all materials identified as having been placed down-hole for the selected nuclear test at NTS. The data for the device, stemming, and rack were relatively easy to assimilate. Data for materials used in the diagnostic on-line detectors are less readily available. Such data can be obtained in more detail, if necessary, but with considerable effort.

Hazardous materials included the special nuclear materials in the device itself, lead and other metals, and (possibly) some organic materials used in detectors.

\section{HAZARDOUS MATERIALS IN NUCLEAR TESTS}

No attempt has been made in this review to evaluate the importance of any given hazardolis material used in nuclear testing. It is useful to try to gain some perspective on this matter. The hazard caused by any material is related to its concentration when encountered; the higher the concentration, the greater the 
hazard. Thus it is useful to consider how materials used for testing may be diluted and dispersed during the testing process.

Furthermore, the hazard of a subterranean material can only come into play if it somehow becomes available to humans. Thus the presence of large amounts of lead may be considered relatively innocuous untll it enters ground water or is mined.

When a riuclear explosion takes place underground, it creates a volume of melted soil. A 1 -kt test w111 melt about $1 \mathrm{kt}$ of the earth's crust. Assuming an average crustal composition, there are about $250 \mathrm{~kg}$ of barium, $15 \mathrm{~kg}$ of gallium, and 5 $\mathrm{kg}$ of arsenic, for example, naturally present in that much material. In addition, the explosion creates a chimney of fractured and crushed material wi.th a much larger volume. This volume of fractured and crushed material is more or less directly associated with the materials added during tecting: more for stemming and materials at or near the top of the rack and less for the materials in the device and its immediate surroundings.

One perspective would be to view the amount of hazardous material added in relation to the amount naturally present in the melt, or in the chimney, as a whole. From such a perspective, the use of a few lillograms or less of arsenic or gallium in a typical test can be viewed as an incremental addition to materials already existing in the geologic medium surrounding the test point. This view is, of course, not applicable to tests with very low, or zero, energy release.

Any hazardous organic materials that are placed outside the melt zone might survive the explosion. Based on current findings, it appears that if any hazardous organic materials have been used, they have been used only in small quantities (generally less than $1-\mathrm{kg}$ amourits). The importance of any such materials would be related to their actual abundance and character, neither of which have been identitied.

Finally, the fissionable materials in the device and the radioactive materials produced during the explosion are clearly important hazardous materials and, with the possible exception of uranium, cannot be considered incremental to natural materials.

\section{REFERENCE}

I. Y. Borg, R. Stone, H. B. Levy, L. D. Ramspott, "Information Pertinent to the Migration of Radionuclides in Ground Water at the Nevada Test Site," Unviversity of California Lawrence Livermore National Lavoratory report UCRL-52078 Pt. 1 (1976). 


\section{HAZARDOUS MATERIALS}

Organic chemicals considered hazardous and regulated under RCRA are listed under 40 CFR Parts 261 and 302; the extensive list is readily available (for example from the Los Alamos National Laboratory Health Safety and Environment Division, HSE). Some common examples are listed below:

Acetone

Carbon tetrachloride

Chlorinated fluorocarbons

Ethyl ether

Methyl ethyl ketone

Toluene

Trichloroethylene

xylene

Hazardous inorganic constituents include those for which the EPA has established limits for concentrations in ground waters, based upon EP-tu..icity ( 40 CFR Chap. 1, Sec. 201.24):

$\begin{array}{lr}\text { Arsenic } & 5 \mathrm{mg} / \mathrm{L} \\ \text { Barium } & 100 \mathrm{mg} / \mathrm{L} \\ \text { Cadmium } & 1 \mathrm{mg} / \mathrm{L} \\ \text { Chromium } & 5 \mathrm{mg} / \mathrm{L} \\ \text { Lead } & 5 \mathrm{mg} / \mathrm{L} \\ \text { Mercury } & 0.2 \mathrm{mg} / \mathrm{L} \\ \text { Selenium } & 1 \mathrm{mg} / \mathrm{L} \\ \text { Silver } & 5 \mathrm{mg} / \mathrm{L}\end{array}$

Other inorganic constituents considered hazardous if present above background levels include those from 40 CFR Chap. 1, Secs, 261 and 302):

Antimony

Asbestos

Beryllium

Copper

Cyanide

Fluoride

Nickel

Osmium

Radionuclides

Thallium

Zinc 

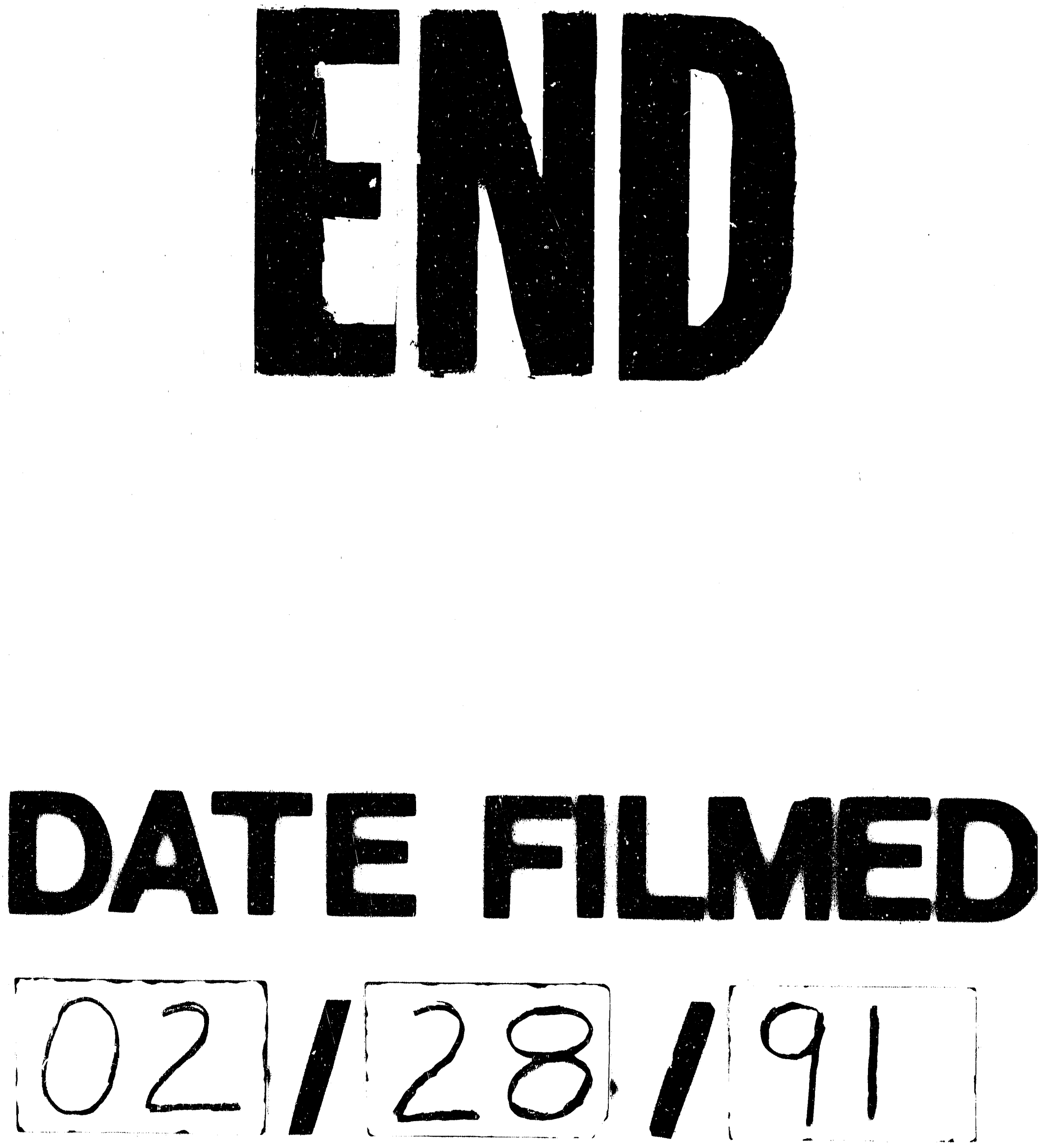
